\title{
Miłosz Markiewicz
}

https://orcid.org/0000-0002-7350-4301

(Katowice)

\section{NOWA WSPÓLNOTA DLA ANTROPOCENU? EKO-LOGIKA, CZYLI MYŚLENIE DOMEM. ZARYS PROBLEMATYKI}

\begin{abstract}
The article is an attempt to review the ecological discourse in the light of posthuman philosophy. The main concept addressed by the author is the Anthropocene; the author observes that the Anthropocene functions as an ambivalent philosophical metaphor, which underlies contemporary ecological discourse. The author advances a new concept which, in his opinion, could replace ecology. The concept is called eco-logics, and may be defined as 'thinking through home'.
\end{abstract}

\section{Key words}

eco-logics, anthropocene, posthumanism, community, ecology 
Podczas poszukiwań punktów stycznych w przestrzeniach posthumanizmu i ekologii co jakiś czas wraca pojęcie, które zdaje się wzbudzać więcej pytań niż dawać odpowiedzi. Nie sposób jednak, myśląc o posthumanistycznej wspólnocie, nie zwrócić uwagi na perspektywę planetarną, zwłaszcza w obliczu powracających doniesień o zmianach klimatycznych czy rosnących ilościach plastiku zalegającego w oceanach. Jak zauważa Ewa Bińczyk, „badacze systemów planetarnych, klimatolodzy, ekonomistki, socjologowie i filozofki w zaangażowany sposób argumentują, że potrzebujemy postantropocentrycznej, środowiskowej czy też klimatycznej korekty naszych pojęć i teorii"'. Sytuacja ta wiąże się nie tylko z rosnącą popularnością posthumanistycznego podejścia, ale także ze wspomnianym pojęciem, które od kilkunastu już lat robi zawrotną karierę w (post)humanistyce - jest nim „antropocen”. W niniejszym artykule zamierzam szerzej przyjrzeć się dyskusji wokół rzeczonego pojęcia, a także spróbować spojrzeć na Antropocen jako postać pojęciową, determinującą obecne współcześnie sposoby myślenia o dychotomii Natury i Kultury. W tym celu przywołam i poddam analizie dyskurs powstały wokół zwiększenia wycinki drzew w nadleśnictwie Białowieża podczas kadencji Jana Szyszki na stanowisku Ministra Środowiska RP. Pozwalam sobie na oparcie swojej argumentacji o ten lokalny i stosunkowo świeży kontekst właśnie z uwagi na jego rozpoznawalność wśród polskich czytelniczek. Zamierzam również zadać pytanie o możliwości wspomnianej postantropocentrycznej redefinicji naszych sposobów postrzegania świata, które - wnoszę - powinny być ufundowane właśnie na świadomości aporii, jakie niesie ze sobą pojęcie antropocenu.

Kiedy w 2000 roku Eugene Stoermer i Paul Crutzen publikowali swój artykuł², zapewne nie przypuszczali, iż kontrowersje związane z ogłoszeniem antropocenu sięgną tak daleko poza stratygrafię czy geologię. Ich celem była przede wszystkim popularyzacja pojęcia, którego sam Stoermer używał ,już od lat osiemdziesiątych ubiegłego stulecia w wykładach publicznych"3. Badacze chcieli zwrócić uwagę na wzmożoną widoczność ingerencji człowieka w planetę, która wymusza według nich pewną zmianę w nazewnictwie epok:

Biorąc pod uwagę (...) poważny i wciąż rosnący wpływ aktywności ludzkiej na ziemię oraz atmosferę, i to w skali globalnej, wydaje się więcej niż właściwe, aby podkreślić centralną rolę rodzaju ludzkiego w geologii i ekologii, poprzez zaproponowanie terminu »antropocen« na oznaczenie aktualnej epoki geologicznej ${ }^{4}$.

\footnotetext{
${ }^{1}$ Bińczyk 2018, s. 15.

${ }^{2}$ Crutzen i Stoermer 2000, s. 17-18.

${ }^{3}$ Birkenmajer 2012, s. 587.

${ }^{4}$ Crutzen i Stoermer 2000, s. 18.
} 
Od 2008 roku prowadzone są prace specjalnego zespołu Międzynarodowej Komisji Stratygrafii, którego celem jest sprawdzenie, czy człowiek rzeczywiście „pozostawił po sobie wyraźny ślad, na tyle mocno utrwalony w warstwach skalnych, że będzie do odczytania jeszcze po upływie dziesiątków lub nawet

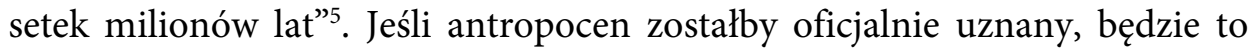
oznaczało, iż geolodzy są w stanie potwierdzić, że sprawczość człowieka równa jest kataklizmom, które do tej pory wyznaczały granice kolejnych epok geologicznych (jak np. zlodowacenie stanowiące cezurę plejstocenu) ${ }^{6}$. Jak zauważa Julia Fiedorczuk, będziemy mogli wtedy „sobie pogratulować - jako gatunek, który entuzjastycznie nadał sobie nazwę Homo sapiens, osiągnęliśmy rozmiary kataklizmu stosunkowo szybko" ". Zanim jednak to nastąpi, geolodzy muszą odpowiedzieć sobie na pytania:

Czy naprawdę ludzie mogli wywierać na Ziemię wpływ równie głęboki, jak ten, który zaczął się wraz z holocenem przed 11700 laty, kiedy to rozległe czapy lodowe zaczęły się topić, podnosząc poziom oceanu światowego o $120 \mathrm{~m}$ ? Czy można porównywać ludzkość z glacjałami, które opanowały Ziemię u zarania plejstocenu, przed 2,6 mln lat? Czy nasza techniczna aktywność z zaledwie kilku ostatnich stuleci może się równać z tymi wszystkimi dramatycznymi wydarzeniami, które znaczyły burzliwą historię geologiczną Ziemi, dzieloną na okresy liczące nierzadko miliony, a nawet miliardy lat?

Antropocen wciąż wzbudza wiele kontrowersji. Nie zmienia to jednak faktu, że wraz z oficjalnym rozpoznaniem ludzkości za siłę geologiczną będziemy musieli „przemyśleć od nowa nie tylko relację pomiędzy naukami przyrodniczymi i społecznymi, ale także historię, współczesność, a nawet samą ideę człowieka" " Zanim to jednak uczynimy, spróbujmy skupić się na propozycjach datowania początków antropocenu.

Crutzen i Stoermer sugerują, aby zwrócić uwagę na końcówkę XVIII wie$\mathrm{ku}$. Powietrze pochodzące $\mathrm{z}$ tego okresu, uwięzione przez setki lat w lodzie polarnym, a poddawane dziś badaniom, wykazuje znaczny wzrost ilości gromadzących się w nim cząstek dwutlenku węgla oraz metanu ${ }^{10}$. To właśnie wtedy powstaje i zostaje wdrożony pierwszy przemysłowy silnik parowy

\footnotetext{
${ }^{5}$ Zalasiewicz 2016, s. 25-26.

${ }^{6} \mathrm{~W}$ chwili obecnej, pomimo rekomendacji udzielonej Międzynarodowej Komisji Stratygrafii przez Grupę Roboczą ds. Antropocenu w dniu 29 sierpnia 2016, oficjalnie nazwa nowej epoki geologicznej nie została przyjęta. Por. Carrington 2016.

${ }^{7}$ Fiedorczuk 2015, s. 11.

${ }^{8}$ Zalasiewicz 2016, s. 24.

${ }^{9}$ Malm i Hornborg 2014, s. 62.

${ }^{10}$ Por. Crutzen i Stoermer 2000; Crutzen 2002.
} 
Jamesa Watta. A więc rewolucja przemysłowa, czyli trzeci okres rozwoju człowieka (po rewolucji poznawczej i agrarnej), stanowiłaby punkt przełomowy nie tylko dla naszego gatunku, ale również dla całej planety ${ }^{11}$. Nieco inaczej proponują datować antropocen badacze skupieni pod przewodnictwem Jana Zalasiewicza. Według nich punktem granicznym powinna stać się pierwsza eksplozja bomby nuklearnej, która miała miejsce 16 lipca 1945 roku w Alamogordo w stanie Nowy Meksyk ${ }^{12}$. To wtedy do atmosfery uwolniona została olbrzymia ilość sztucznie wytworzonych radioaktywnych nuklidów, które rozprzestrzeniły się po całej planecie, wpływając na strukturę chemiczną jej warstwy geologicznej. Ta perspektywa byłaby więc zapewne bliższa Międzynarodowej Komisji Stratygrafii, jako że obserwacje Crutzena, badacza atmosfery $^{13}$, nie znajdują uznania w oczach wielu geologów.

Obie przywoływane propozycje skupiają się na „momentach” w naszej historii, które - trudno temu zaprzeczyć - zmieniły jej bieg. Zarówno rewolucja przemysłowa, jak i użycie bomby atomowej wprowadziły świat na nowe tory. Byłoby to więc zgodne $\mathrm{z}$ samą etymologią pojęcia antropocenu - na które składają się łacińskie anthropos (człowiek) oraz cene (nowe; od gr. kainos) - oznaczającą, iż mamy do czynienia z całkowicie nowym światem, którego siłę napędową stanowi człowiek. Właśnie dlatego niektórym badaczom tak trudno zgodzić się na oficjalne uznanie antropocenu i dlatego prowadzone nad nim badania geologiczne muszą być tak dokładne. Ów „nowy świat" miałby bowiem oznaczać dosłownie m.in. nowy skład chemiczny planety, a co za tym idzie, nowe sposoby funkcjonowania żyjących na niej organizmów. Tak jak w przypadku poprzednich epok geologicznych - wpływ człowieka na Ziemię musiałby być liczony (a w tym przypadku prognozowany) w setkach tysięcy lat. Czy rzeczywiście zdążyliśmy już tak bardzo zmienić naszą planetę? O czym jeszcze mówi nam propozycja antropocenu?

Karol Birkenmajer, jeden z krytyków uznania nowej epoki geologicznej, postrzega wprowadzenie terminu „antropocen” za bezużyteczne dla badaczy zajmujących się planetą. Pojęcie to ma dla niego raczej charakter etyczny i symboliczny. Pisał, że „termin ten może być (...) przydatny dla geografów ekonomicznych, planistów, działaczy ochrony przyrody, socjologów itp., ale

\footnotetext{
${ }^{11}$ Por. Harari 2014.

${ }^{12}$ Por. Zalasiewicz, Waters i Williams 2015.

${ }^{13}$ W 1995 roku Paul J. Crutzen otrzymał Nagrodę Nobla w dziedzinie chemii za swoje badania nad antropogennym niszczeniem warstwy ozonowej.
} 
nie dla stratygrafów, paleogeografów czy paleobiologów”14. I rzeczywiście trudno uznać, iż nie ma racji. W przeciwieństwie do nauk przyrodniczych humanistyka dosyć szybko oswoiła się z nowym terminem, wprowadzając go do użycia przede wszystkim w środowisku związanym $\mathrm{z}$ myślą posthumanistyczną. Antropocen to chociażby jeden z lejtmotywów książki Rosi Braidotti „Po człowieku”15. Choć również na tym gruncie spotyka się z krytyką.

Przykładowo Donna Haraway jest sceptyczna wobec jego używania, zwracając m.in. uwagę, że przecież człowiek od początków swojego istnienia miał znaczący wpływ na funkcjonowanie planety ${ }^{16}$, a więc wydzielanie nowego okresu w tej skomplikowanej relacji jest nadużyciem ${ }^{17}$. Dodatkowo filozofka próbuje pytać, jak posthumanistyczna krytyka definicji Człowieka ${ }^{18}$ ma się do terminu „antropocen”. Człowiek jest pojęciem, które na przestrzeni wieków zmieniało swoje granice i było używane w celu kategoryzowania rzeczywistości. Ustalało hierarchię i budowało mury poprzez procesy włączania oraz wyłączania ze swojego obrębu. Właściwie już od starożytności widzimy, że nie każdy mógł sobie zasłużyć na miano Człowieka, a z biegiem czasu zmieniały się jedynie kryteria, które pozwalały dostąpić tej uprzywilejowanej pozycji ${ }^{19}$. Dlatego też Haraway pyta w kontekście definiowania antropocenu:

Anthropos - co to takiego? Wszyscy Homo sapiens sapiens? Cały rodzaj ludzki? No więc kto dokładnie? Ludzkość używająca paliw kopalnych to najkrótsza pasująca odpowiedź. Przemysłowa ludzkość - a pojęcie to wciąż ma przecież charakter gatunkowy. Nie odwołuje się do całej ludzkości okresu przemysłowego, ale do konkretnych formacji globalnego kapitału ${ }^{20}$.

\footnotetext{
${ }^{14}$ Birkenmajer 2012, s. 588 .

${ }^{15}$ Por. Braidotti 2014.

${ }^{16}$ Wędrówki Homo sapiens doprowadziły przecież do wyginięcia wielu gatunków roślin i zwierząt, nie mówiąc już o innych przedstawicielach rodzaju Homo- (Harari 2014)

${ }^{17}$ Por. Haraway 2015.

${ }^{18}$ W myśl posthumanistycznej teorii krytycznej, rozróżniam „dwa rodzaje ludzi”, które zaznaczam odmiennie - dla łatwiejszego zrozumienia tej wykładni. Zdecydowałem się na używanie dużej litery na oznaczenie "Człowieka” jako abstrakcyjnego pojęcia, figury myślenia (czy też - jak chcieliby Gilles Deleuze i Félix Guattari - postaci pojęciowej) - w odróżnieniu od „człowieka”, reprezentującego (biologicznie rozumiany) rodzaj/gatunek ludzki. W tekstach z kręgu myśli posthumanistycznej znajdziemy też pojęcie Anthropos obok używanego przeze mnie pojęcia Człowieka.

${ }^{19}$ Znamienne, że Rosi Braidotti rozpoczyna swoją książkę słowami: „Nie wszyscy możemy powiedzieć z jakimkolwiek stopniem pewności, że zawsze byliśmy ludźmi - albo że jesteśmy tylko ludźmi. Niektórzy z nas nawet dzisiaj nie są uznawani za w pełni ludzkich - a co dopiero w przeszłości, w społecznej, politycznej i naukowej historii Zachodu" (Braidotti 2014, s. 45).

${ }^{20}$ Por. Haraway i Keney 2015, s. 259. Haraway nawiązuje tu - choć nie wprost - do pojęcia kapitalocenu, użytego po raz pierwszy przez Andreasa Malma (Malm i Hornborg 2014), a spopularyzowanego przez Jasona Moore'a (Moore 2016).
} 
Do podobnych wniosków dochodzi Eva Hayward, która twierdzi, że uznanie antropocenu wiąże się z pewną manipulacją - sugestią, że wszyscy jesteśmy Anthropos. Również ci, którzy do tej pory byli wykluczeni z tej definicji, zostają na nowo do niej włączeni (a więc, nawiązując do przywołanej już etymologii antropocenu, powstaje „nowy Człowiek”), by wspólnie odpowiadać za działania uprzywilejowanej dotychczas grupy ${ }^{21}$.

Pomimo - niewątpliwie potrzebnej - krytyki pojęcia antropocenu warto zwrócić na nie uwagę jako na pojemną filozoficzną metaforę. Antropocen ma bowiem charakter ambiwalentny. $Z$ jednej strony przeraża nas wizja tak daleko idącego wpływu na planetę i całe znajdujące się na niej życie. Z drugiej, termin ten wydaje się pociągający, ujawnia bowiem realny charakter siły, jaka tkwi w człowieku. Sugeruje jednak również pewien potencjał działania.

\begin{abstract}
Od poprzednich katastrof różnimy się tym, że - przynajmniej w teorii - możemy mieć świadomość tego, czym jesteśmy i jaka jest natura naszych związków z innymi elementami ożywionej i nieożywionej przyrody. Mamy też możliwość - przynajmniej potencjalną - obserwowania konsekwencji swoich działań i wyciągania wniosków. Crutzen i Stoermer są zdania, że nastanie antropocenu to przede wszystkim wielkie wyzwanie dla ludzkiej myśli ${ }^{22}$.
\end{abstract}

I właśnie owa ambiwalencja wydaje się tym, co w antropocenie najciekawsze. Wspomniane „wyzwanie dla ludzkiej myśli” posiada niejednoznaczny charakter - nie sugeruje, w jakim kierunku myśl ta powinna zmierzać. Samo pojęcie antropocenu stara się bowiem utrzymać neutralny charakter - nie jest oceną, a jedynie stwierdzeniem pewnego stanu rzeczy.

Tym, na co chciałbym zwrócić szczególną uwagę, jest pojawiająca się tu metafora-paradoks, który nazywam "człowiekiem na bezludnej wyspie”. $\mathrm{Z}$ jednej strony, próbujemy opisać zastaną rzeczywistość z perspektywy dystansu, odciąć się na chwilę od ludzkiej ingerencji w planetę, by spróbować podjąć próbę jej opisu w sposób - w miarę - całościowy. Z drugiej zaś strony, już sama obecność człowieka sprawia, iż dystans ów jest niemożliwy. Nie możemy na chwilę wyłączyć się z ekosystemu. Bezludna wyspa pozostaje bezludna, dopóki człowiek nie postawi na niej stopy - jego pojawienie się uruchamia sieć różnorodnych relacji, w tym procesy fizyczne i biochemiczne. Nie da się więc opisać bezludnej wyspy w jej dziewiczym stanie. Wiara w tego

${ }^{21}$ Teza wygłoszona na wykładzie Evy Hayward „Whalin’, Whale In” na Uniwersytecie Karola w Pradze 26 sierpnia 2016 roku podczas spotkania w ramach programu „New Materialism. Networking European Scholarship on «How matter comes to matter»" (COST IS1307).

${ }^{22}$ Fiedorczuk 2015, s. 11-12. 
typu opis zbliża nas raczej do romantycznej wizji Natury, którą znajdujemy chociażby w pismach Jana Jakuba Rousseau - dobrej, dopóki pozostaje nieoswojona $^{23}$. Powinniśmy zdać sobie sprawę $\mathrm{z}$ tego, iż podział na Naturę i Kulturę nie da się dalej utrzymać. Możemy raczej mówić o - jak chciałaby Haraway - naturokulturze ${ }^{24}$. Zwłaszcza, gdy pójdziemy tropem wspomnianej już konstatacji, że człowiek - jak każde inne zwierzę - funkcjonuje w relacjach z planetą i ekosystemem już od początku pojawienia się na Ziemi całego rodzaju Homo. Każda próba „ratunku planety” będzie się więc wiązała z niemożliwą do cofnięcia ingerencją w jej stan, powodowaną próbą zniwelowania skutków wcześniejszej ingerencji.

Podczas kadencji Jana Szyszki na stanowisku Ministra Środowiska RP uchwalony został aneks do Planu Urządzenia Lasu w nadleśnictwie Białowieża na lata 2012-2021. Zakładał on zwiększenie wycinki drzew z 63,4 tys. $\mathrm{m}^{3}$ do 188 tys. $\mathrm{m}^{3}$. Działanie to było uzasadniane gradacją kornika drukarza na terenach Puszczy, w których zwiększona została wycinka ${ }^{25}$. Decyzja ta spotkała się z silnym sprzeciwem środowisk ekologicznych. W związku z tym Ministerstwo Środowiska podjęło szereg kroków, których celem było przekonanie społeczeństwa o konieczności ludzkiej ingerencji w Puszczy Białowieskiej - w celu m.in. ratowania charakterystycznej dla niej bioróżnorodności. Jednym z takich kroków była współorganizacja wraz z Wyższą Szkołą Kultury Społecznej i Medialnej w Toruniu konferencji „Puszcza Białowieska mity, fakty i przyszłość", która miała miejsce w dniach 12-13 marca 2016. W efekcie tej konferencji powstał dokument, który został następnie udostępniony przez Ministerstwo Środowiska. Czytamy tam, iż:

prezentowana część Puszczy Białowieskiej to dziedzictwo kulturowe miejscowej ludności od wieków użytkowane przez nią dla dobra człowieka i dobra przyrody. (...) Unikatowy stan zasobów przyrodniczych, objawiający się unikatową bioróżnorodnością jest więc także dziedzictwem kulturowym miejscowej ludności, która zgodnie z wiedzą i nauką z zakresu leśnictwa wiedziała jak użytkować Puszczę, aby służyła ona człowiekowi i stan jej nie ulegał pogorszeniu.

Nieco dalej znajdziemy zaś akapit o następującej treści:

Puszcza Białowieska to dzieło rąk ludzkich. To ewidentne dziedzictwo kulturowo-przyrodnicze, którego podmiotem jest miejscowa ludność. To z tego powodu Puszcza zasługuje na wpisanie jej na listę dziedzictwa kulturowego UNESCO. Może być to

\footnotetext{
${ }^{23}$ Por. Rousseau 1956.

${ }^{24}$ Por. Haraway 2012.

${ }^{25}$ Por. PAP 2016.
} 
bardzo dobrym przykładem harmonijnego współdziałania człowieka i przyrody dla dobra zarówno człowieka jak i przyrody ${ }^{26}$.

Proponowana tu retoryka wydaje się nazbyt oczywista - Puszcza Białowieska została stworzona przez człowieka i to właśnie człowiekowi powinna służyć. Dlatego też bardziej niż dziedzictwem naturalnym jest ona dziedzictwem kulturowym $^{27}$. To do człowieka należy prawo zarządzania Puszczą, a także podejmowania decyzji o tym, co jest dla niej dobre, a co złe. To ludzie są tu bowiem podmiotami, a Puszcza to jedynie przedmiot ich troski.

Wydaje się jednak, że niewielka jest różnica pomiędzy powyższym podejściem, a tym prezentowanym przez tzw. organizacje ekologiczne. Przykładowo WWF reklamuje się hasłem "Chronimy przyrodę z ludźmi i dla ludzi”. Sposób myślenia obrońców środowiska dobrze oddaje Edward O. Wilson, twórca terminu „socjobiologia” i zaangażowany działacz na rzecz ochrony przyrody, gdy pisze:

Reszta stulecia będzie wąskim gardłem rosnącego wpływu człowieka na środowisko i kurczenia się bioróżnorodności. Jest sprawą naszej odpowiedzialności przeprowadzenie siebie i maksimum reszty życia przez to wąskie gardło do raju zrównoważonego istnienia. Nasz wybór będzie miał charakter głęboko moralny. (...) Tylko my jedni spośród wszystkich gatunków postrzegamy realność świata życia, widzimy piękno przyrody i przyznajemy wartość jednostce. Tylko my doceniamy wartość miłosierdzia wobec bliźnich. Czy rozszerzymy teraz tę perspektywę na świat życia, który nas zrodził? ${ }^{28}$

Mamy w tym przypadku do czynienia z retoryką niebezpiecznie bliską tej, którą odnajdujemy we wnioskach dotyczących Puszczy Białowieskiej, choć wydawałoby się, że autor tych słów stanąłby po przeciwnej niż Jan Szyszko stronie barykady. Wilson sugeruje, że jedynym ratunkiem dla „reszty życia” jest właściwa ingerencja człowieka, którego wyjątkowość polega na dostrzeganiu piękna przyrody i docenianiu miłosierdzia. To w rękach ludzkości leży przyszłość świata, który powinien stać się przedmiotem naszej troski.

U podstaw obu zaprezentowanych sposobów myślenia stoi pojęcie Antropocenu (rozumianego jako postać pojęciowa) ${ }^{29}$. To właśnie ono każe nam myśleć o Człowieku - jako nie tylko sile sprawczej zachodzących w przyrodzie

\footnotetext{
${ }^{26}$ Szyszko, Terlecki i Klafka 2016. Podkreślenia moje.

${ }^{27}$ A może właśnie, by przywołać wspomniane już przeze mnie pojęcie Donny Haraway, staje się przestrzenią naturokulturową.

${ }^{28}$ Wilson 2016, s. 122.

${ }^{29}$ Tak jak w przypadku „człowieka/Człowieka”, będę używał dużej litery na oznaczenie „Antropocenu” jako figury myślowej/metafory, podczas gdy mianem „antropocenu” określał będę epokę geologiczną.
} 
zmian, ale także jedynym ratunku dla zmieniającej się planety. Postawa zbudowana na Antropocenie nie tylko zakłada naprawę tego, co się „zepsuło”, ale także prewencyjne działania, mające niejako wyjść naprzeciw możliwym „kataklizmom”. Opiera się ona na przekonaniu o niezwykłej umiejętności Człowieka - umiejętności „właściwej” ingerencji w otaczający go świat, związanej z posiadaniem wiedzy „co jest dobre dla planety” 30 . Antropocen zwraca uwagę na Człowieka jako przyczynę zmian zachodzących w przyrodzie, ale równocześnie sugeruje, że to właśnie Człowiek jest jedyną siłą będącą w stanie coś $\mathrm{z}$ tymi zmianami zrobić. I powinien uczynić to $\mathrm{w}$ retoryce sprawnego zarządzania.

To, co ekologiczne, jest bowiem polityczne. Antropocen uczy nas, że samodzielnie działająca natura to mit. Przekonuje, iż sekretem sukcesu naszego „właściwego” życia na planecie są dobrze podejmowane decyzje, w których przyroda jest wyłącznie przedmiotem. Także Paul Crutzen pisał, że

\begin{abstract}
rodzaj ludzki pozostanie główną siłą mającą wpływ na środowisko przez wiele tysiącleci. Trudne zadanie stoi przed naukowcami i inżynierami, którzy muszą poprowadzić społeczeństwo ku stabilizującemu zarządzaniu środowiskiem w epoce antropocenu ${ }^{31}$.
\end{abstract}

Nie rozważał więc opcji współpracy z otaczającym go światem, a jedynie władanie nim i kierowanie.

Tak rozumiany Antropocen okazuje się więc esencją antropocentryzmu - jego zwieńczeniem i ostateczną wygraną ${ }^{32}$. Jako pojęcie z zakresu geologii zwraca naszą uwagę na rzeczywisty wpływ człowieka na środowisko życia. Jako figura myślenia przenosi ów wpływ w przestrzeń abstrakcyjną, ustawiając według własnych zasad nasze sposoby postrzegania planety oraz zamieszkującego je życia. Wydaje się, że Antropocen stanowi klucz do zrozumienia pętli, w jakiej zamknął się dyskurs ekologiczny. Dotarł on bowiem do miejsca, w którym przeciwstawne sobie strony używają takich samych argumentów - o potrzebie dbania o środowisko, właściwego zarządzania przyrodą

\footnotetext{
${ }^{30}$ Por. Bonneuil i Fressoz 2013.

${ }^{31}$ Crutzen 2002, s. 23.

${ }^{32}$ Więcej o antropocentryzmie stojącym u podstaw pojęcia antropocenu można znaleźć także w: Bonneuil i Fressoz 2013, Hamilton 2017. Clive Hamilton, którego stanowisko w tej kwestii jest mi bliskie, pisze w tym kontekście o „nowym antropocentryzmie” oraz konieczności jego podwójnego ujęcia - zarówno jako centralnej geologicznej siły sprawczej, jak i poczucia ludzkiej wyjątkowości. „Jakkolwiek przekonujące nie byłyby rozmaite sposoby krytyki centralnego miejsca rodzaju ludzkiego, zostają one wręcz zdmuchnięte przez antropocen, który legitymizuje raz na zawsze centralne miejsce ludzkości na Ziemi” (Hamilton 2017, s. 37).
} 
i regulowania jej funkcjonowania. Choć wydawałoby się, iż dyskurs ekologiczny jest ostatnim miejscem, w którym poszukiwalibyśmy antropocentryzmu, odnajdziemy tam jego piętno.

Timothy Morton wskazywał na ciekawą zbieżność - Michel Foucault umiejscawia początki definicji Człowieka w postaci, pod jaką znamy ją dzisiaj, w końcu XVIII wieku, a więc w tym samym okresie, w którym Crutzen i Stoermer chcieliby widzieć początki antropocenu ${ }^{33}$. Symbolicznie więc moglibyśmy uznać koniec XVIII wieku za narodziny nowoczesnej relacji Człowieka i Natury. W tym przypadku oba te terminy miałyby jednak charakter odcieleśniony, przeniesiony do sfery abstrakcyjnych koncepcji, które stają się figurami naszego myślenia. Na przecięciu obu wspomnianych wyrasta zaś trzecia - Antropocen. To właśnie w nim spotykają się i sprzęgają definicje Człowieka i Natury.

Dopóki będziemy rozpatrywać planetę $\mathrm{w}$ kategoriach troski i odpowiedzialności, dopóty nie uda nam się uwolnić od myślenia Antropocentrycznego. Ufundowana na Antropocenie ekologia zawodzi, nie potrafi wyjść poza kategorie sprawnego zarządzania i poszukiwanie rozwiązania w Człowieku. Jak głosi wspomniane już hasło - „chronimy przyrodę z ludźmi i dla ludzi”. Ekologia uprawiana w takim tonie ma tak naprawdę tylko jeden obiekt troski, a jest nim sam człowiek. Warto pamiętać o tym, że dotychczasowe katastrofy, które wyznaczały kolejne epoki geologiczne, nie zabiły planety, a jedynie ją zmieniały. Żyjemy w czasach, które Edward O. Wilson nazywa „wilczym gardłem”, ale to nie losy planety, a przyszłość gatunku ludzkiego okazuje się niepewna. Jak bowiem zauważa Timothy Morton, „antropocen to nazwa masowego wymierania - szóstego podczas 4,5 miliarda lat życia na Ziemi" ${ }^{34}$. Okazuje się więc Antropocen opowieścią o autodestrukcji, samozagładzie, którą fundujemy naszemu gatunkowi. Antropocen-tryczna ekologia jest próbą ochrony człowieka poprzez przemawianie do jego empatii. Podsycana jest strachem przed tym, że jeśli nie zadbamy o środowisko, to tym bardziej nie będziemy potrafili zadbać o siebie ${ }^{35}$. Wszakże "globalne ocieplenie nie jest tylko zagrożeniem politycznym, ale także ontologicznym"36. Zwiększające się nasycenie dwutlenku węgla w atmosferze czy wybijanie kolejnych gatunków zwierząt tworzących ekosystem to prosta droga do kresu ludzkości. Planeta

${ }^{33}$ Por. Morton 2014, s. 258.

${ }^{34}$ Morton 2014, s. 258.

${ }^{35}$ Jedno z haseł akcji Adoptuj pszczołę prowadzonej przez organizację Greenpeace brzmi: „Jeśli wymrzemy, zabieramy was ze sobą".

${ }^{36}$ Morton 2018, s. 290. 
przeżyła już jednak gorsze kataklizmy niż to, co funduje jej Człowiek. Ziemia jest bowiem hiperobiektem, a więc jej istnienie przekracza ramy naszego rozumowania ${ }^{37}$. Żyła długo przed nami i będzie funkcjonowała jeszcze długo po tym, gdy nasz gatunek zniknie z jej powierzchni. Znamy tylko jej wycinek i nie jesteśmy w stanie poznać więcej. Nawet gdybyśmy dysponowali bardzo szczegółowymi badaniami na temat przeszłości i przyszłości - wciąż będzie to tylko fragment z całej historii i sposobu funkcjonowania planety.

Być może nadszedł więc czas uświadomić sobie, że Człowiek nie jest światu potrzebny. Wręcz przeciwnie - to Człowiek potrzebuje świata i to w takiej wersji, w jakiej go sobie stworzył. Świata ufundowanego na Antropocenie, poddającego się Ludzkiej woli i potrzebom. Dalsze kierowanie się Antropocentryczną wizją rzeczywistości prowadzi jedynie do nieuchronnego końca. Dlatego nadchodzi wspomniana już potrzeba przemyślenia naszego związku z ekosystemem. Dopiero zarzucenie dotychczasowego myślenia i wyjście w kierunku postantropocentryzmu (a może nawet post-Antropocentryzmu) pozwoli nam uwolnić się spod władzy Antropocenu. Nie oznacza to oczywiście nagłego odnalezienia ratunku dla człowieka. Przyjęcie postantropocentrycznej optyki pozwala nam patrzeć i myśleć „szerzej”. Nie każe nam decydować o tym, co jest dobre dla planety. Nie przekonuje nas także, że powinniśmy spróbować dowiedzieć się, „co myśli góra”, jak chcieliby to robić przedstawiciele tzw. ekologii głębokiej ${ }^{38}$. Zwraca raczej naszą uwagę na egalitarność wszystkich istnień i sugeruje pogodzenie się ze świadomością, iż nie tylko nie jesteśmy wyjątkowi, ale także że nigdy nie zrozumiemy całego życia i zasad nim rządzących. Oparty na postantropocentrycznej optyce posthumanizm proponuje więc współistnienie - dla wszystkich na takich samym zasadach. Odrzuca relację podmiotu i przedmiotu jako hierarchiczną, sugerując iż wszystko posiada taki sam - relacyjny - status. Oznacza to, iż nie jesteśmy nigdy po jednej stronie takich relacji, ale że zawsze istniejemy wewnątrz nich, w samym ich sercu. Nasze życie i funkcjonowanie ma charakter relacyjny i doświadczamy tego chociażby oddychając. Otaczający nas świat przepływa przez nas, a my jesteśmy jedną z jego części. Nie rozmywamy się jednak, a zawsze pozostajemy sobą, ucieleśnieni i usytuowani ${ }^{39}$. Oto podstawa do tworzenia nowego sposobu ujmowania naszego współ-życia z przyrodą.

\footnotetext{
${ }^{37}$ Por. Morton 2013.

${ }^{38}$ Por. Devall i Sessions 1995.

${ }^{39}$ Por. Markiewicz 2015.
} 
Przyjrzyjmy się terminowi „ekologia”, składającemu się ze słów oĩko

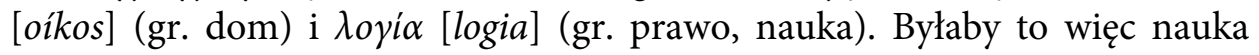
o domu, o jego prawach i zasadach funkcjonowania. Jest to zgodne $\mathrm{z}$ powszechnym rozumieniem tej dziedziny - zwłaszcza kwestia domu, a więc miejsca, w którym zamieszkujemy i o które powinniśmy dbać, w którym powinniśmy utrzymywać porządek. Jak już jednak zauważyliśmy, pojawia się tu pewien problem. Wbrew pozorom ekologia nie służy bowiem domowi, a jego szczególnemu mieszkańcowi, jakim jest człowiek. To właśnie on sprząta i porządkuje dom, to on ustanawia prawa w nim rządzące. Ufundowana na Antropocenie ekologia czyni z Człowieka swoją centralną figurę, nie dostrzega jego relacyjności, a pozostałych mieszkańców domu traktuje przedmiotowo. Być może dzieje się tak dlatego, że istnieje jeszcze jedna logia,

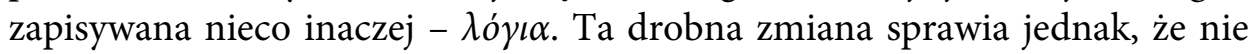
mamy tu do czynienia z prawem czy nauką, ale z fragmentem tekstu wyjętym z kontekstu. I właśnie owo skupienie na nieusytuowanym, abstrakcyjnym fragmencie (a więc Człowieku) w przypadku ekologii już sobie uświadomiliś-

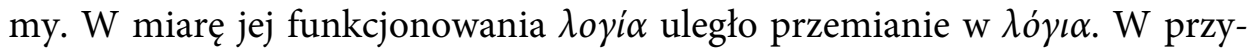
padku ufundowanej na Antropocenie ekologii działamy tak, jakby wycinek rzeczywistości, jakim jest Człowiek, funkcjonował na zasadzie pars pro toto. Nie tylko nie znamy kontekstu naszego istnienia w świecie, ale także próbujemy działać tak, jakby jedyne znane nam zasady obowiązywały wszystko, co nas otacza. Tak jest chociażby $z$ nadawaniem praw zwierzętom czy roślinom. Nie potrzebują naszych zasad dopóki nie zaczynamy ingerować w ich życie. W tym kontekście należałoby zadać pytanie, dla kogo w istocie nadawane są owe prawa. Oczywiście trudno nie zauważyć, że nasze życia są sprzęgnięte i nieustannie „wchodzimy sobie w drogę", jednak powinniśmy spróbować znaleźć dla siebie taki rodzaj współ-życia $\mathrm{z}$ otaczającym nas środowiskiem, który wszystkie byty, wszystkich domowników (w tym i nas) traktowałby tak samo.

Dlatego też ekologia musi zawieść. Proponuję, by jej miejsce zajęła eko-logika. Posiada ona podobne, choć jednak znacząco odmienne elementy

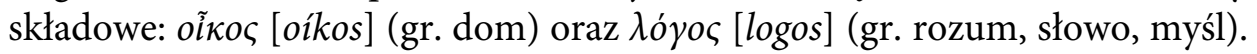
Zamiast więc zasad domu skupmy się na domu jako zasadzie naszego myślenia. Na myśleniu domem. „Dom jest mikroświatem, wiedzą o świecie”40. I właśnie tę wiedzę o świecie spróbujmy z domu wydobyć. Dom eko-logiki jest

\footnotetext{
${ }^{40}$ Kulas 2011, s. 59.
} 
bowiem o wiele większy - to już nie mikroświat, a świat-sam-w-sobie. Eko-logika pozwala uruchomić myślenie w perspektywie posthumanistycznej wspólnoty, dla której jedyną zasadą jest współ-życie czy też bycie razem w przestrzeni jednego życia, zoe. Jeśli więc rzeczywiście chcemy współżyć z planetą, postrzegać siebie jako jej - równą innym - część, to u podstaw naszego funkcjonowania powinna stanąć post-Antropocen-tryczna koncepcja eko-logiki. Myśleć domem to porzucić wszelkie centryzmy ${ }^{41}$. Jedynym możliwym centrum byłby tu dom, rozumiany jednak jako hiperobiekt, którego ścian i granic nie jesteśmy w stanie dostrzec ani pojąć. To dom, który poddany jest nieustającej samoorganizacji, stawaniu-się. Wszystko, co $\mathrm{z}$ nami w tym domu współ-żyje, miałoby więc tak samo centralny charakter jak człowiek. Myśleć domem to żyć ze sobą, w egalitarnej wspólnocie istnień, współpracować i współfunkcjonować.

Dom musi tu jednak być rozumiany jako „przestrzeń przynależności”, a nie „przestrzeń przynależna" ${ }^{2}$. To dom, który nie posiada właściciela, a jedynie mieszkańców. Przede wszystkim zaś eko-logika miałaby stanowić rodzaj myśli wspólnotowej na miarę Antropocenu. Byłaby próbą przekreślenia metafory człowieka na bezludnej wyspie, owego romantycznego mitu ustanawiającego dialektykę Natury i Kultury. Eko-logiczna wspólnota wiązałaby się z jednością współ-życia i współzamieszkiwania, ale owa jedność nie funkcjonowałaby na zasadzie czystości, a raczej współistnienia oraz współpracy wszystkich domowników. To wspólnota, która staje-się-domem. Nie jest ona oparta na konkretnym terytorium - należy bowiem pamiętać, że, jak zauważał Homi K. Bhabha, terytorium to „ziemia, która odstrasza”43. Także dlatego, że przestrzeń owego domu, ustanawianego przez eko-logikę, nie miałaby charakteru przestrzeni w rozumieniu euklidesowym. Chodzi więc raczej o zadomowienie w życiu i współ-życiu, dla którego nadrzędna jest zasada egalitarności współmieszkańców, przy czym dla definiowania mieszkańców proponuję przyjęcie perspektywy postantropocentrycznej.

Zdaję sobie doskonale sprawę, że przywołana tu koncepcja eko-logiki wymaga rozwinięcia i doprecyzowania ${ }^{44}$. To jedynie zarys, wstępna propozycja,

\footnotetext{
${ }^{41}$ Zdaję sobie oczywiście sprawę z niedoskonałości tego sformułowania. Skupienie się na „myśleniu" sugeruje zwrot ku racjonalności, jednak w kontekście eko-logiki niezwykle ważne wydaje mi się wyjście poza dualizm umysłu i ciała, a więc zwrot w kierunku poznania ucieleśnionego, czy też „rozumienia estetycznego”. Por. Markiewicz 2017.

${ }^{42}$ Morley 2011, s. 33-34.

${ }^{43}$ Bhabha 2012, s. 97.

${ }^{44} \mathrm{Nad}$ czym obecnie pracuję, co - mam nadzieję - znajdzie wyraz w kolejnych publikacjach w tym zakresie.
} 
której poszczególne elementy wymagają dokładnego opracowania w dalszych badaniach. Potrzebuje ona chociażby uzupełnienia o konkretne propozycje przekraczania Antropocen-tryzmu zarówno w dyskursie, jak i działaniu. Kwestia ucieczki od „centryzmów” również wydaje się o tyle istotna do szczegółowego opracowania, iż wymaga niezwykłej wrażliwości, pozwalającej na balansowanie pomiędzy przeciwnościami - tak, by eko-logika nie stała się jedną z postaw, z krytyki których wyrasta. Również samej figurze „domu” należy się doprecyzowanie. Na potrzeby niniejszego tekstu pozwalam ją sobie jednak pozostawić $\mathrm{w}$ pewnym niedookreśleniu, raczej w celu zaznaczenia pola do namysłu niż zamknięcia tematu. Mam nadzieję, iż dalsze rozwijanie koncepcji eko-logiki, pozwoli na ucieczkę z pułapki Antropocen-tryzmu.

\section{THE NEW COMMUNITY FOR THE ANTHROPOCENE? ECO-LOGICS, OR THINKING THROUGH HOME. INITIAL THOUGHTS}

\section{Summary}

The article is an attempt to review the ecological discourse in the light of posthuman philosophy. The main concept addressed by the author is the Anthropocene: the name of the new geological epoch, which betokens growing influence of human practices on the condition of Earth. Analyzing the concept of the Anthropocene, the author outlines its history, to date critique and related controversies (within natural sciences and humanities). The author also observes that the Anthropocene functions as an ambivalent philosophical metaphor, which underlies contemporary ecological discourse. In an attempt to challenge Anthropocene-tric thought, the author advances a new concept which, in his opinion, could replace ecology. The concept is called eco-logics, and may be defined as 'thinking through home'.

\section{Bibliografia}

Bhabha H.K. 2010, Miejsca kultury, przeł. T. Dobrogoszcz, Kraków.

Bińczyk E. 2018, Epoka człowieka. Retoryka i marazm antropocenu, Warszawa.

Birkenmajer K. 2012, Antropocen - nowa epoka geologiczna?, Przegląd Geologiczny, 11.

Bonneuil C. i Fressoz J.-B. 2013, The Shock of The Anthropocene. The Earth, History and Us, przeł. D. Fernbach, Londyn-Nowy York.

Braidotti R. 2014, Po człowieku, przeł. J. Bednarek, A. Kowalczyk, Warszawa.

Carrington D. 2016, The Anthropocene Epoch: Scientists Declare Dawn of Human-influenced Age, The Guardian, 29.08.16.

Crutzen P.J. i Stoermer E. 2000, The “Anthropocene”, Global Change Newsletter, 41. 
Crutzen P.J. 2002, Geology of Mankind, Nature, 415.

Devall B. i Sessions G. 1995, Ekologia głęboka. Żyć w przekonaniu, iż Natura coś znaczy, przeł. E. Margielewicz, Warszawa.

Fiedorczuk J. 2015, Cyborg w ogrodzie. Wprowadzenie do ekokrytyki, Gdańsk.

Harari Y.N. 2014, Od zwierząt do bogów. Krótka historia ludzkości, przeł. J. Hunia, Warszawa.

Haraway D. 2012, Manifest gatunków stowarzyszonych, przeł. J. Bednarek, [w:] A. Gajewska (red.), Teorie wywrotowe. Antologia przekładów, Poznań.

Haraway D. i Keney M. 2015, Anthropocene, Capitalocene, Chthulhucene. Donna Haraway in conversation with Martha Kenney, [w:] H. Davis, E. Turpin (red.), Art in the Anthropocene. Encounters Among Aesthetics, Politics, Environments and Epistemologies, London.

Haraway D. 2015, Anthropocene, Capitalocene, Plantationocene, Chthulucene: Making Kin, Environmental Humanities, 6.

Kulas D. 2011, Dom - to, co istotne, Anthropos?, 16-17.

Malm A. i Hornborg A. 2014, The geology of mankind? A critique of the Anthropocene narrative, The Anthropocene Review, 1.

Markiewicz M. 2015, Przekroczyć człowieka. Uwagi o postantropocentrycznym problemie umiejscowienia, Anthropos?, 24.

Markiewicz M. 2017, Świat poza dualizmami. Pytania o rozumienie estetyczne w kontekście nowego materializmu, Magazyn antropologiczno-społeczno-kulturowy MASKA, 34.

Morley D. 2011, Przestrzenie domu. Media, mobilność i tożsamość, przeł. J. Mach, Warszawa.

Morton T. 2013, Hyperobjects. Philosophy and Ecology after the End of the World, Minneapolis.

Morton T. 2014, How I Learned to Stop Worrying and Love the Term Anthropocene, Cambridge Journal of Postcolonial Literary Inquiry, 1.

Morton T. 2018, Lepkość, przeł. A. Barcz, Teksty drugie, 2.

PAP 2016, Co dalej z Puszczą Białowieską? [online]. National Geographic [dostęp: 2018-11-24]. Dostępny w Internecie: <http://www.national-geographic.pl/aktualnosci/co-dalej-z-puszczabialowieska-minister-zapowiada-eksperyment-ekolodzy-sa-przeciw $>$.

Rousseau J.J. 1956, Rozprawa o pochodzeniu i podstawach nierówności między ludźmi, przeł. H. Elzenberg, [w:] idem, Trzy rozprawy z filozofii społecznej, Warszawa.

Szyszko J., Terlecki R. i Klafka Z. 2016, Sprawozdanie z przebiegu wraz z wnioskami Konferencji naukowej na temat: „Puszcza Białowieska - mity, fakty i przyszłość” [online]. MOS [dostęp: 2019-11-23]. Dostępny w Internecie: <https://www.mos.gov.pl/fileadmin/ user_upload/mos/Aktualnosci/marzec_2016/Sprawozdanie_Bialowieza_PDF.pdf >.

Wilson E.O. 2016, Znaczenie ludzkiego istnienia, przeł. B. Baran, Warszawa.

Zalasiewicz J., Waters C. i Williams M. 2015, When did the Anthropocene begin? A midtwentieth century boundary level is stratigraphically optimal, Quaternary International, 383.

Zalasiewicz J. 2016, Ludzki ślad na Ziemi, Scientific American, 10 (302). 